\title{
Apple production and quality when cultivated under anti-hail cover in Southern Brazil
}

\author{
Leosane Cristina Bosco - Homero Bergamaschi • Loana Silveira Cardoso • \\ Viviane Aires de Paula • Gilmar Arduino Bettio Marodin • \\ Gilmar Ribeiro Nachtigall
}

Received: 23 February 2014 / Revised: 16 August 2014 / Accepted: 20 August 2014

(C) ISB 2014

\begin{abstract}
Anti-hail nets may change the microclimate of orchards and hence modify the physicochemical and sensory characteristics of fruits. The present study aimed to evaluate the effects of anti-hail nets on the physical, chemical, and sensory attributes of apples grown in southern Brazil. The study was conducted in commercial orchards, with apples grown under a black anti-hail net under an open sky during the 2008/2009, 2009/2010, and 2010/2011 cycles. Measurements of photosynthetically active radiation were collected at both sites. Physical, chemical, and sensory analyses of fruits were performed in the laboratory. The anti-hail
\end{abstract}

L. C. Bosco ( $\square)$

Department of Agronomy Sciences, Federal University of Santa Catarina, Rodovia Ulysses Gaboardi, Km 3, Curitibanos, Santa Catarina 89520-000, Brazil

e-mail: leosane@gmail.com

\section{H. Bergamaschi}

Department of Forage Plants and Agrometeorology, Federal

University of Rio Grande do Sul, Av. Bento Gonçalves, Porto Alegre,

Rio Grande do Sul 7712, Brazil

\section{S. Cardoso}

Meteorological Center of Rio Grande do Sul, State Foundation for Agricultural Research, Rua Gonçalves Dias, Porto Alegre, Rio

Grande do Sul 570, Brazil

V. A. de Paula

Federal Institute of Rio Grande do Sul, Av. Leonel de Moura Brizola, Bagé, Rio Grande do Sul 2501, Brazil

\section{G. A. B. Marodin}

Department of Horticulture and Silviculture, Federal University of Rio Grande do Sul, Av. Bento Gonçalves, Porto Alegre, Rio Grande do Sul 7712, Brazil

\section{G. R. Nachtigall}

Temperate Fruit Crops Experimental Station, Brazilian Enterprise for Agricultural Research Grape and Wine (Embrapa Uva e Vinho), Vacaria, Rio Grande do Sul, Brazil net reduced incident photosynthetically active radiation by $32 \%$. The light spectrum in the canopy changed the corresponding R/FR (red/far-red) ratio in the lower and upper canopy layers from 0.27 to 1.55 , respectively. In contrast to the majority of microclimate studies carried out in the temperate zones of the northern hemisphere, this study in the southern hemisphere showed that although it reduced the incident solar radiation, the cover did not change the color or organoleptic characteristics of "Royal Gala" and "Fuji Suprema" apples. The net cover prolonged the subperiod between fruit setting and harvesting, thus slowing fruit ripening. Therefore, the use of anti-hail nets on apple orchards is a suitable alternative for the protection of apple trees against hail because it causes only small changes in the microclimate and in the maturation period, ensuring fruit production without affecting its quality.

Keywords Malus domestica $\cdot$ Microclimate $\cdot$ Fruit color · Soluble solids $\cdot$ Acidity $\cdot$ Sensory analysis

\section{Introduction}

The occurrence of hail events in the apple producing region of southern Brazil has increased the use of anti-hail protection nets over orchards. The anti-hail net is a physical barrier installed over an orchard that is intended to protect the plants against damage by hail and strong wind and to reduce damage from birds. In apples, the net also reduces sunburn and russeting, providing better color and skin uniformity (Middleton and McWaters 2002; Amarante et al. 2011).

Fruit quality is a genetic trait that is influenced by environmental conditions. Under protected cultivation, the interactions between plants and the environment occur differently than they do under the open sky due to changes in various 
microclimatic variables that may influence the quality of fruits or vegetables (Tanny et al. 2009; Tanny 2013).

The efficiency of anti-hail nets in protecting orchards and their possible effects on fruit quality have been addressed in several studies. However, there have been only a few studies on the effect and efficiency of this technique on apple trees in Brazil. Studies conducted by Leite et al. (2002) and Amarante et al. $(2007,2009,2011)$ in southern Brazil showed that anti-hail nets reduce the color intensity of fruits. Leite et al. (2002) also observed a lower incidence of russeting on apples cultivated under nets, with no changes in the soluble solids, acidity, starch, or pulp firmness. However, Amarante et al. (2007, 2009) observed that the cover did not influence the occurrence of russeting on apples.

In apple orchards in Argentina, anti-hail nets reduced the color, soluble solids, pulp firmness, and sunburn of fruits (Dussi et al. 2005). In Slovenia, apples grown under black hail protection nets also exhibited reduced color and sunburn damage; however, the fruit color varied more as a result of the temperature range between day and night during maturation than due to the availability of solar radiation (Stampar et al. 2002). In Spain, the use of black nets caused reductions in soluble solids, color intensity, and starch conversion but did not affect pulp firmness or titratable acidity (Iglesias and Alegre 2006). In South Africa, the cover reduced the fruit firmness, soluble solids, and titratable acidity, with the color of fruits varying among cultivars and years (Smit 2007). The results obtained by Guerrero-Prieto et al. (2010) in Mexico showed that black anti-hail protection nets did not influence the development or color of apples. In Germany, Solomakhin and Blanke (2010a) observed that the hail net affected the quality of apples, reducing their firmness and vitamin $\mathrm{C}$ content. However, the sugar/acidity ratio, which is considered an indicator of fruit flavor, was not affected by the net (Solomakhin and Blanke 2010b).

Given the results obtained under different conditions and in different regions of the world, it is observed that the color of apples is the characteristic most influenced by covering the apple trees with anti-hail nets, with varying results depending on cultivar, latitude, and orchard management. Since fruit color and other physicochemical characteristics are crucial at the time of commercialization, it is important that apple producers have research-driven information regarding the use of anti-hail protection nets, thereby improving the cover system and the management of plants under protected cultivation. Therefore, the present study hypothesizes that coverage by a black anti-hail net affects the quality and taste of the "Royal Gala" and "Fuji Suprema" apples produced in southern Brazil. Based on that hypothesis, the objective of this study was to evaluate the effects of anti-hail nets on the physical, chemical, and sensory attributes of apples grown in southern Brazil.

\section{Materials and methods}

The experiment was conducted in commercial apple orchards in Vacaria, southern Brazil at a $930 \mathrm{~m}$ altitude, latitude of $28^{\circ}$ $24^{\prime} 52.5^{\prime \prime} \mathrm{S}$ and longitude of $50^{\circ} 50^{\prime} 53.8^{\prime \prime} \mathrm{W}$ during three production cycles $(2008 / 2009,2009 / 2010$, and 2010/2011).

According to the Köppen classification, the regional climate is $\mathrm{Cfb}$, with temperate summers (Alvares et al. 2013). In this region, the maximum, minimum, and mean air temperatures have wide annual temperature ranges, and the amount of rainfall and number of days with rain are distributed throughout the year (Pereira et al. 2009). The mean air temperature in Vacaria is $16.2^{\circ} \mathrm{C}$. July is the coldest month $\left(11.2^{\circ} \mathrm{C}\right)$, and January is the warmest month $\left(20.6^{\circ} \mathrm{C}\right)$. The mean annual maximum and minimum air temperatures are 21.9 and $10.3{ }^{\circ} \mathrm{C}$, respectively. The number of chilling hours below $7.0^{\circ} \mathrm{C}$ accumulated during the cold season is approximately 800 (Cardoso et al. 2012). The mean monthly rainfall varies between 115 and $203 \mathrm{~mm}$, and the annual mean is approximately $1,900 \mathrm{~mm}$ (Cardoso 2011).

The soils of the region are classified as brown oxisol, with a mildly undulated to undulated relief and high contents of clay and aluminum (Embrapa 2006).

The apple cultivars evaluated were "Royal Gala" and "Fuji Suprema", established in 1999 with M9 rootstock. "Royal Gala" was the main cultivar, whereas "Fuji Suprema" was the secondary, or pollinator, cultivar. To obtain adequate pollination, the plants were distributed as three lines of "Royal Gala" interspersed with a line of "Fuji Suprema". The orchard was established at a high density, with $1.0 \mathrm{~m}$ between plants and $3.5 \mathrm{~m}$ between rows. The apple orchard planting system was central leader with support. This system has a pyramid-shaped tree with tiers of branches spaced along the trunk. The branches are fixed in structures with horizontal wires. The plant lines were oriented in a north-south direction.

The orchard was divided into blocks, two of which were used for the experiment (one in front of the other), with 200 plants each. The plants in the north block were covered with an anti-hail net, whereas the plants in the south block were kept with open sky (without the net). The anti-hail net was black in color with a mesh of $4 \times 7 \mathrm{~mm}$. The net was mounted on a fixed structure in 2000, 1 year after planting the seedlings. On the frame structure, the net formed two pitches, with a 20-cm opening between the lines for the eventual hail runoff. Another area of the orchard was kept under the open sky and was located at a distance of $15 \mathrm{~m}$ from the first. Both blocks were cultivated with the same cultivars and management practices.

Orchard management was conducted following the specific technical standards for Integrated Apple Production recommended by the Brazilian Ministry of Agriculture, Livestock and Supply (NTEPI 2006). 
The photosynthetically active radiation (PAR) measurements for the orchard were monitored from 09/18/2008 to 04/30/2011 under open-air conditions and under the anti-hail net and in different "Royal Gala" canopy strata encompassing the entire profile of the plants. Measurements of PAR were collected through bars with five amorphous silicon photovoltaic cells facing upwards. The incident PAR sensors were installed at ground level and at $0.8,1.5$, and $2.7 \mathrm{~m}$ above ground. The radiation quality was determined on $03 / 31 / 2010$ between $11 \mathrm{am}$ and 1:30 pm (local time) and without the presence of clouds. A portable LI-COR Model LI-1800 spectro-radiometer was used. Measurements were made at three canopy layers of the "Fuji Suprema" plants (upper, middle, and lower) and interrows of plants at ground level. Three measurements were taken at each layer and between the rows and the mean used for comparison of treatments. To minimize possible differences due to the time of the measurements, these were obtained in order of the following layers: upper layer, middle layer, lower layer, and interrow. Each measurement was performed first under the net and then, immediately after, under open sky. The light spectrum analyzed ranged from 300 to $800 \mathrm{~nm}$.

The PAR sensors were connected to automatic data acquisition systems (Campbell CR21X datalogger) with readings taken every $30 \mathrm{~s}$ and recorded every $30 \mathrm{~min}$ during the three production cycles. To quantify the effects of the environment on PAR, analysis of variance of the linear regressions was performed using the $F$ test.

To evaluate the physicochemical characteristics of the apples, all of the fruits from 10 marked "Royal Gala" plants and five marked "Fuji Suprema" plants were harvested under open sky and under the anti-hail net. The harvest was performed at fruit maturation, taking into account the measured levels of total soluble solids (TSS; 12 "Brix for "Royal Gala" and $13{ }^{\circ}$ Brix for "Fuji Suprema") and the visual assessment of fruit color. From each plant, all of the fruits were harvested separately in two layers, with the upper layer corresponding to the upper half of the plant and the lower layer to the lower half. The fruits were packed in previously labeled boxes, counted and weighed while still at the orchard. Samples were then collected for laboratory testing. For each plant level, 15 fruits were collected, totaling 30 fruits per plant from each environment and cultivar. These fruits were transported to the Postharvest Laboratory and maintained in cold storage.

The variables measured and analyzed in the laboratory included skin color, incidence of russeting, pulp firmness, total titratable acidity (TTA), and TSS.

The skin color of each sampled apple was randomly measured once. This determination was performed using a Konica/Minolta CR400 colorimeter according to the CIELAB system proposed by the Commission Internationale de L'Eclaraige in $L^{*} a^{*} b^{*}$. The $L$ value corresponds to a luminosity scale and represents the lightness of the colors, ranging from 0 to $100(0=$ black, $100=$ white $)$. For " $a$ ", the scale ranges from -60 to +60 , where a negative " $a$ " is green, and positive is red. For " $b$ ", the scale ranges from -60 to +60 , where a negative " $b$ " is blue, and positive is yellow. In this system, a color representation is given by four different parameters: luminosity, hue angle, chromaticity, and color index. The hue or color angle indicates the location of the color in a diagram where an angle of $0^{\circ}$ corresponds to pure red, $90^{\circ}$ to pure yellow, $180^{\circ}$ to pure green, and $270^{\circ}$ to pure blue. The hue angle was calculated using the equation $\mathrm{Hue}=\arctan$ $(b / a) \times 57.3$, where " $a$ " and " $b$ " represent the values obtained with the colorimeter reading. The chroma indicates the color intensity and is defined by the hue angle distance at the center of the three-dimensional diagram; it was calculated by the equation Chroma $=\left(a^{2}+b^{2}\right)^{0.5}$. The color index allows for a direct correlation with assessments of the visual appearance of the fruits, which is calculated by Color index $=a / b$.

The incidence of russeting was based on visual classification, in which russeting was considered to be absent when the fruit had no visual symptoms or when the symptom was restricted to the stem cavity, and it was considered to be present when the fruit had symptoms on over $10 \%$ of its surface.

To measure pulp firmness, the skin was first removed on two opposite sides of the fruit along the median transverse plane. Subsequently, a manual penetrometer was used to measure the force (in Newtons) necessary to overcome the resistance of the pulp tissue by the compression exerted by the $11-\mathrm{mm}$ diameter tip. The penetration depth of the tip was approximately $1 \mathrm{~cm}$.

The TTA was determined by titrating apple juice diluted with $0.1 \mathrm{~N}$ sodium hydroxide until reaching $\mathrm{pH}$ 8.1. A pH meter (Digimed DM-20) equipped with a thermal compensator was used. The apple juice was obtained by centrifuging the pulp, from which a 6-g sample was diluted with $90 \mathrm{~mL}$ of distilled water. The calculation of the acidity was performed according to the equation $A=V \times N \times 0.67 \times(100 / G)$, where $A$ is the total acidity in meq malic acid per $100 \mathrm{~mL}, V$ is the $\mathrm{NaOH}$ volume spent in the titration, $N$ is the normality of $\mathrm{NaOH}, 0.67$ is a factor to express the malic acid acidity in meq, and $G$ is the mass $(6 \mathrm{~g})$ of the sample.

The TSS level was obtained from two to three drops of juice, which were removed from the homogenized sample. A portable digital refractometer (Pocket PAL-1) with $\pm 0.2 \%$ accuracy was used. The reading was expressed as ${ }^{\circ}$ Brix. The TSS/TTA ratio was obtained from the TSS and TTA values.

The experimental design was completely randomized, and in each "Royal Gala" cultivation environment, ten previously marked plants were used, distributed in five rows (two plants per row), with each plant representing a replicate. For "Fuji Suprema", five plants distributed in a row were used, with each plant also representing a replicate. The rows lateral to these plants formed the borders, together with 12 plants at the edge. Two sources of variations were considered: the 

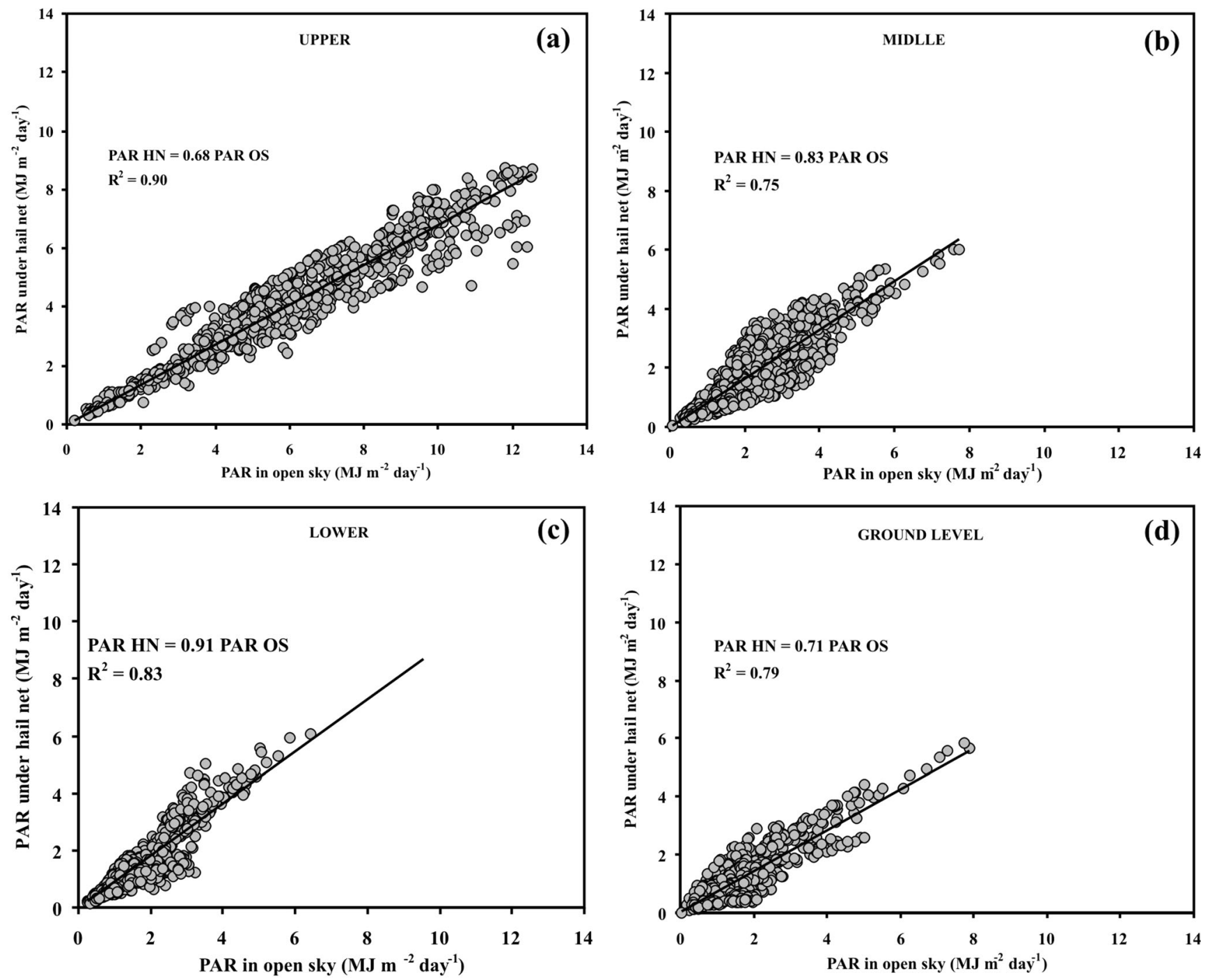

Fig 1 Photosynthetically active radiation $(P A R)$ incident at $2.7 \mathrm{~m}$ upper (a), at $1.5 \mathrm{~m}$ middle (b), at $0.8 \mathrm{~m}$ lower (c), and at ground level (d) strata of the "Royal Gala" apple tree canopy under the anti-hail net $(H N)$ as a

environment and the canopy layer, as the analyses of each cycle and each cultivar were performed separately. The treatment means of all evaluated variables were subjected to Bartlett, Kolmogorov-Smirnov, and Durbin-Watson tests to verify whether they presented homogeneity of variance, a normal distribution, and data independence, respectively. These conditions were confirmed, and then an analysis of variance was performed to quantify the effect of the variation sources. When this analysis was significant $(F$ test), the means were separated by Tukey's test. Statistical significance was tested at a $5 \%$ probability of error.

For the sensory analysis, a sample of 30 "Royal Gala" and "Fuji Suprema" apples from each growing environment (under the anti-hail net and under open sky) were collected on the days of commercial harvest, taking into account the level of TSS and color. Among these fruits, 15 were used for the physicochemical

function of incident PAR in the open sky (OS) in the 2008/2009, 2009/2010, and 2010/2011 cycles, Vacaria, RS, Brazil. Linear regressions were significant according to the $F$ test $(p \leq 0.05)$

analysis (weight, diameter, color, firmness, TTA, and TSS). Another 15 fruits were used for sensory analysis, performed in the Sensory Analysis Laboratory of the Food Science and Technology Institute (FSTI) on 03/ 25/2010 ("Royal Gala") and 04/29/2010 ("Fuji Suprema") between $2 \mathrm{pm}$ and $5 \mathrm{pm}$ (local time).

A total of 34 individuals (students and teachers) from FSTI who consume apples weekly were selected. The individuals were not informed of the purpose of the analysis to avoid influencing their assessment during tasting. An acceptance test was performed using a hedonic scale (expressing the degree of product like or dislike) and statistical evaluation by analysis of variance. The acceptance test used is a descriptive method, as it involves both the discrimination and the description of the sensory attributes of the product assessed.

The fruits from each treatment were cut into four parts through the longitudinal axis. The sampled specimens 
Table 1 Fruit color indices: Hue angle $\left({ }^{\circ} \mathrm{h}\right)$, color index, and chroma on apple fruits in the upper and lower layers of the canopies of "Royal Gala" and "Fuji Suprema" under the open sky and anti-hail net protection in the 2008/2009, 2009/2010, and 2010/2011 cycles, Vacaria, RS, Brazil

\begin{tabular}{|c|c|c|c|c|c|c|c|c|c|}
\hline \multirow[t]{2}{*}{ Environment } & \multicolumn{3}{|c|}{ Coloring $\left({ }^{\circ} \mathrm{h}\right)$} & \multicolumn{3}{|c|}{ Color index } & \multicolumn{3}{|c|}{ Chroma } \\
\hline & Upper & Lower & Mean & Upper & Lower & Mean & Upper & Lower & Mean \\
\hline \multicolumn{10}{|c|}{ "Royal Gala" 2008/2009 cycle } \\
\hline Open sky & 33.8 & 38.3 & $36.1 \mathrm{~A}$ & 1.5 & 1.2 & $1.4 \mathrm{~A}$ & 38.6 & 38.1 & $38.4 \mathrm{~A}$ \\
\hline Hail net & 32.6 & 34.9 & $33.8 \mathrm{~A}$ & 1.2 & 1.2 & $1.2 \mathrm{~A}$ & 36.9 & 38.5 & $37.7 \mathrm{~A}$ \\
\hline Mean & $33.2 \mathrm{a}$ & $36.6 \mathrm{a}$ & & $1.4 \mathrm{a}$ & $1.2 \mathrm{a}$ & & $37.8 \mathrm{a}$ & $38.3 \mathrm{a}$ & \\
\hline \multicolumn{10}{|c|}{ "Royal Gala" 2009/2010 cycle } \\
\hline Open sky & 37.8 & 40.0 & $38.9 \mathrm{~A}$ & 1.4 & 1.3 & $1.4 \mathrm{~A}$ & 43.9 & 43.6 & $43.8 \mathrm{~A}$ \\
\hline Hail net & 39.7 & 40.8 & $40.3 \mathrm{~A}$ & 1.2 & 1.1 & $1.2 \mathrm{~A}$ & 43.1 & 40.8 & $42.0 \mathrm{~A}$ \\
\hline Mean & $38.8 \mathrm{a}$ & $40.4 \mathrm{a}$ & & $1.3 \mathrm{a}$ & $1.2 \mathrm{a}$ & & $43.5 \mathrm{a}$ & $42.2 \mathrm{a}$ & \\
\hline \multicolumn{10}{|c|}{ "Royal Gala" 2010/2011 cycle } \\
\hline Open sky & - & - & - & - & - & - & - & - & - \\
\hline Hail net & 36.6 & 28.6 & 32.6 & 1.4 & 1.4 & 1.4 & 38.2 & 40.0 & 39.1 \\
\hline Mean & - & - & & - & - & & - & - & \\
\hline \multicolumn{10}{|c|}{ "Fuji Suprema" 2008/2009 cycle } \\
\hline Open sky & 34.8 & 31.2 & $33.0 \mathrm{~A}$ & 0.7 & 0.4 & $0.6 \mathrm{~A}$ & 31.4 & 33.5 & $32.5 \mathrm{~A}$ \\
\hline Hail net & 41.6 & 33.0 & $37.3 \mathrm{~A}$ & 0.9 & 0.8 & $0.9 \mathrm{~A}$ & 34.5 & 34.5 & $34.5 \mathrm{~A}$ \\
\hline Mean & $38.2 \mathrm{a}$ & $32.1 \mathrm{a}$ & & $0.8 \mathrm{a}$ & $0.6 \mathrm{a}$ & & $33.0 \mathrm{a}$ & $34.0 \mathrm{a}$ & \\
\hline \multicolumn{10}{|c|}{ “Fuji Suprema” 2009/2010 cycle } \\
\hline Open sky & 50.1 & 61.3 & $55.7 \mathrm{~A}$ & 0.9 & 0.6 & $0.8 \mathrm{~A}$ & 36.7 & 37.1 & $36.9 \mathrm{~A}$ \\
\hline Hail net & 49.5 & 54.9 & $52.2 \mathrm{~A}$ & 0.9 & 0.6 & $0.8 \mathrm{~A}$ & 33.4 & 32.5 & $33.0 \mathrm{~A}$ \\
\hline Mean & $49.8 b$ & $58.1 \mathrm{a}$ & & $0.9 \mathrm{a}$ & $0.6 \mathrm{a}$ & & $35.1 \mathrm{a}$ & $34.8 \mathrm{a}$ & \\
\hline \multicolumn{10}{|c|}{ "Fuji Suprema" 2010/2011 cycle } \\
\hline Open sky & - & - & - & - & - & - & - & - & - \\
\hline Hail net & 28.9 & 23.4 & 26.2 & 0.7 & 0.6 & 0.7 & 31.6 & 31.1 & 31.4 \\
\hline Mean & - & - & & - & - & & - & - & \\
\hline
\end{tabular}

Uppercase letters in the column of the mean and lowercase letters on the line of the mean when they are significantly different from each other by Tukey's test $(p \leq 0.05)$. The en dash $(-)$ indicates no data due to the total loss of production under the open sky because of the incidence of hail

consisted of a portion of the fruit from each treatment. The identification of the treatments was encoded. The analysis was performed in individual white booths with natural lighting, with a panel of 34 tasters selected according to the criteria previously described. Each taster received a glass of water, the two samples coded with three random digits, and a sensory evaluation record.

The evaluation form used was designed to quantify the samples' perceived quality through the following sensory analysis components: visual attributes-acceptance of the intensity and color tone; taste attributes - acceptance of the intensity, structure, balance, and quality; overall acceptability attributes - degree of overall product like or dislike. These characteristics were evaluated in nine interval or ratio scales as follows: (1) extremely disliked, (2) disliked very much, (3) disliked moderately, (4) disliked slightly, (5) not liked or disliked, (6) liked slightly, (7) liked moderately, (8) liked very much, and (9) extremely liked. Comparison of the results was performed by analysis of variance.

\section{Results}

The average of the three production cycles indicated a $32 \%$ reduction in PAR under the anti-hail net compared to PAR under the open sky for the upper layer of the apple tree canopy. In the middle and lower layers of the canopy and at ground level, the PAR under the net was 17, 9, and $29 \%$ lower than the open-sky PAR, respectively (Fig. 1). The average PAR transmissivity at ground level was higher than at the middle and lower layers because the sensors were located below the limit of the canopy, where there are no branches or leaves near the sensors. The observed variability in the distribution of PAR along the profile of the canopy may be attributed to variations in the distribution of the leaf area and therefore in the distinct interaction of solar radiation with the leaves of the apple trees.

The "Royal Gala" fruits under the anti-hail net were harvested on 03/04/2009, 02/18/2010, and 03/18/2011. Harvesting under the open sky section was conducted on 
Table 2 Flesh firmness and incidence of russeting on apple fruits in the upper and lower strata of the canopies of "Royal Gala" and "Fuji Suprema" under the open sky and anti-hail net protection in the 2008/2009, 2009/2010, and 2010/2011 cycles, Vacaria, RS, Brazil

\begin{tabular}{|c|c|c|c|c|c|c|}
\hline \multirow[t]{2}{*}{ Environment } & \multicolumn{3}{|c|}{ Flesh firmness $(N)$} & \multicolumn{3}{|c|}{ Russeting (\%) } \\
\hline & Upper & Lower & Mean & Upper & Lower & Mean \\
\hline \multicolumn{7}{|c|}{ "Royal Gala" 2008/2009 cycle } \\
\hline Open sky & 79.7 & 77.3 & $78.5 \mathrm{~A}$ & 89 & 89 & $89 \mathrm{~A}$ \\
\hline Hail net & 77.5 & 76.1 & $76.8 \mathrm{~A}$ & 82 & 82 & $82 \mathrm{~B}$ \\
\hline Mean & $78.6 \mathrm{a}$ & $76.7 \mathrm{a}$ & & $86 a$ & $86 a$ & \\
\hline \multicolumn{7}{|c|}{ "Royal Gala" 2009/2010 cycle } \\
\hline Open sky & 79.4 & 75.8 & $77.6 \mathrm{~A}$ & 79 & 69 & $74 \mathrm{~A}$ \\
\hline Hail net & 66.7 & 65.5 & $66.1 \mathrm{~B}$ & 77 & 78 & $78 \mathrm{~A}$ \\
\hline Mean & $73.1 \mathrm{a}$ & $70.7 \mathrm{a}$ & & $78 \mathrm{a}$ & $74 \mathrm{a}$ & \\
\hline \multicolumn{7}{|c|}{ "Royal Gala" 2010/2011 cycle } \\
\hline Open sky & - & - & - & - & - & - \\
\hline Hail net & 66.6 & 66.1 & 66.4 & 60 & 65 & 63 \\
\hline Mean & - & - & & - & - & \\
\hline \multicolumn{7}{|c|}{ "Fuji Suprema" 2008/2009 cycle } \\
\hline Open sky & 68.6 & 67.0 & $67.8 \mathrm{~A}$ & 35 & 62 & $49 \mathrm{~A}$ \\
\hline Hail net & 70.3 & 68.5 & $69.4 \mathrm{~A}$ & 49 & 55 & $52 \mathrm{~A}$ \\
\hline Mean & $69.5 \mathrm{a}$ & $67.8 \mathrm{a}$ & & $42 \mathrm{a}$ & $59 \mathrm{a}$ & \\
\hline \multicolumn{7}{|c|}{ "Fuji Suprema" 2009/2010 cycle } \\
\hline Open sky & 68.2 & 66.3 & $67.3 \mathrm{~A}$ & 52 & 62 & $57 \mathrm{~A}$ \\
\hline Hail net & 64.3 & 58.6 & $61.5 \mathrm{~B}$ & 50 & 53 & $52 \mathrm{~A}$ \\
\hline Mean & $66.3 \mathrm{a}$ & $62.3 \mathrm{a}$ & & $51 \mathrm{a}$ & $58 \mathrm{a}$ & \\
\hline \multicolumn{7}{|c|}{ "Fuji Suprema" 2010/2011 cycle } \\
\hline Open sky & - & - & - & - & - & - \\
\hline Hail net & 63.9 & 66.6 & 65.3 & 56 & 70 & 63 \\
\hline Mean & - & - & & - & - & \\
\hline
\end{tabular}

Uppercase letters in the column of the mean and lowercase letters on the line of the mean indicate when they are significantly different from each other by Tukey's test $(p \leq 0.05)$. The en dash $(-)$ indicates no data due to the total loss of production under the open sky because of hail

02/17/2009 and 02/04/2010; however, there was no harvesting during the 2010/2011 production cycle due to a total loss of fruits caused by hail. The "Fuji Suprema" fruits under the antihail net were harvested on 04/29/2009, 04/08/2010, and 04/ $27 / 2011$. For this cultivar, the harvests of fruits grown under the open sky took place on $04 / 15 / 2009$ and $03 / 26 / 2010$, with no harvest in 2010/2011 due to the total loss caused by hail.

The results of the physicochemical analyses of fruits produced under different environments indicated that there was an interaction between the canopy layers and the environment, with no significant differences among the canopy layers in the different fruit quality parameters evaluated (Tables 1, 2, and 3).

The fruit color did not differ between the environments for any cycle or cultivar. The hue angle, color index, and chroma exhibited no significant differences between their environments during the two cycles evaluated (Table 1). Therefore, the results suggest that the anti-hail net did not influence the fruit color, even with microclimatic changes under the net (Fig. 1).

The firmness of the "Royal Gala" and "Fuji Suprema" fruit pulp did not differ between environments in the 2008/2009 cycle; however, it was significantly higher under the open sky for both cultivars in 2009/2010 (Table 2).

Russeting is a physiological disorder that leaves the skin of the fruits rough and with a brown color, reducing their classification and their economic value. The occurrence of russeting on apples results from damage to the cuticle, especially during the initial period of fruit formation. It can occur due to a number of factors but is primarily due to cultivar susceptibility, exposure to the environment, and cultural practices (Faust and Shear 1972). This disorder was found in fruits under the anti-hail net and under the open sky during the three production cycles. However, in the 2008/2009 cycle, we observed significant differences between the environments, with russeting occurring in 89 and $82 \%$ of the "Royal Gala" fruits under the open sky and under the net, respectively. In the "Fuji Suprema" fruits, the incidence of russeting was less pronounced than it was in "Royal Gala", and it did not differ between environments (Table 2). After the evaluation of five cycles, Noé and Eccher (1996) and Leite et al. (2002) concluded that there was a reduction in the russeting of apples under nets due to the shading they caused. However, those authors used nets to protect the fruits from damage caused by direct solar radiation; therefore, those nets reduced the incident radiation to a greater degree than did the anti-hail net used in the present study.

For "Royal Gala", there were differences in the acidity of the fruits between the environments, and the mean TTA was $17 \%$ higher under the net in 2008/2009, whereas in 2009/2010 it was $11 \%$ higher under the open sky. The TSS and the TSS/TTA ratio did not differ between the environments for "Royal Gala" (Table 3). In the "Fuji Suprema" fruits, the acidity and soluble solids levels and the TSS/TTA ratio did not differ between the environments in the two cycles evaluated (Table 3).

Sensory analysis uses the senses of sight, smell, touch, and taste as measuring instruments to assess and quantify food characteristics (Dutcosky 2011). The fruits from each environment were collected at different times due to the delayed maturation of the fruits under the net and were maintained in cold storage for a period of less than 50 days. The "Royal Gala" fruits under the open sky were redder, with a higher acidity, pulp firmness, and fruit mass and lower levels of TSS than those under the net. The fruit size for "Royal Gala" apples did not differ between the environments. The "Fuji Suprema" apples produced under the open sky were less reddish, with higher acidity, TSS, and mass than those produced under anti-hail net. However, the flesh firmness did not differ between the environments, and the fruit size was smaller in apples grown under the open sky.

Even with the differences in the physicochemical characteristics evaluated in the laboratory, the attributes of appearance, skin color, sweet flavor, acid flavor, and 
Table 3 Total titratable acidity (TTA), total soluble solids (TSS), and TSS/TTA ratio of apple fruits in the upper and lower strata of the "Royal Gala" canopy under the open sky and anti-hail net protection in the 2008/2009, 2009/2010, and 2010/2011 cycles, Vacaria, RS, Brazil

\begin{tabular}{|c|c|c|c|c|c|c|c|c|c|}
\hline \multirow[t]{2}{*}{ Environment } & \multicolumn{3}{|c|}{ TTA (meq. malic acid/100 mL) } & \multicolumn{3}{|c|}{ TSS ( ${ }^{\circ}$ Brix $)$} & \multicolumn{3}{|c|}{ TSS/TTA } \\
\hline & Upper & Lower & Mean & Upper & Lower & Mean & Upper & Lower & Mean \\
\hline \multicolumn{10}{|c|}{ "Royal Gala" 2008/2009 cycle } \\
\hline Open sky & 2.6 & 2.7 & $2.7 \mathrm{~B}$ & 12.5 & 12.4 & $12.5 \mathrm{~A}$ & 4.8 & 4.8 & $4.8 \mathrm{~A}$ \\
\hline Hail net & 3.1 & 3.3 & $3.2 \mathrm{~A}$ & 12.4 & 12.1 & $12.3 \mathrm{~A}$ & 4.4 & 3.9 & $4.2 \mathrm{~A}$ \\
\hline Mean & $2.9 \mathrm{a}$ & $3.0 \mathrm{a}$ & & $12.5 \mathrm{a}$ & $12.3 \mathrm{a}$ & & $4.6 \mathrm{a}$ & $4.4 \mathrm{a}$ & \\
\hline \multicolumn{10}{|c|}{ "Royal Gala" 2009/2010 cycle } \\
\hline Open sky & 4.9 & 4.5 & $4.7 \mathrm{~A}$ & 14.2 & 13.8 & $14.0 \mathrm{~A}$ & 2.9 & 3.1 & $3.0 \mathrm{~A}$ \\
\hline Hail net & 4.3 & 4.1 & $4.2 \mathrm{~B}$ & 13.8 & 13.3 & $13.6 \mathrm{~A}$ & 3.2 & 3.3 & $3.3 \mathrm{~A}$ \\
\hline Mean & $4.6 \mathrm{a}$ & $4.3 \mathrm{a}$ & & $14.0 \mathrm{a}$ & $13.6 \mathrm{a}$ & & $3.1 \mathrm{a}$ & $3.2 \mathrm{a}$ & \\
\hline \multicolumn{10}{|c|}{ "Royal Gala" 2010/2011 cycle } \\
\hline Open sky & - & - & - & - & - & - & - & - & - \\
\hline Hail net & 2.6 & 2.6 & 2.6 & 13.3 & 12.9 & 13.1 & 4.7 & 4.9 & 4.8 \\
\hline Mean & - & - & & - & - & & - & - & \\
\hline \multicolumn{10}{|c|}{ "Fuji Suprema" 2008/2009 cycle } \\
\hline Open sky & 2.4 & 2.3 & $2.4 \mathrm{~A}$ & 15.9 & 15.6 & $15.8 \mathrm{~A}$ & 6.8 & 6.7 & $6.8 \mathrm{~A}$ \\
\hline Hail net & 2.4 & 2.3 & $2.4 \mathrm{~A}$ & 15.8 & 15.0 & $15.4 \mathrm{~A}$ & 6.8 & 6.5 & $6.7 \mathrm{~A}$ \\
\hline Mean & $2.4 \mathrm{a}$ & $2.3 \mathrm{a}$ & & $15.9 \mathrm{a}$ & $15.3 \mathrm{a}$ & & $6.8 \mathrm{a}$ & $6.6 \mathrm{a}$ & \\
\hline \multicolumn{10}{|c|}{ "Fuji Suprema" 2009/2010 cycle } \\
\hline Open sky & 4.0 & 3.9 & $4.0 \mathrm{~A}$ & 16.7 & 16.2 & $16.5 \mathrm{~A}$ & 4.2 & 4.2 & $4.2 \mathrm{~A}$ \\
\hline Hail net & 4.2 & 3.7 & $4.0 \mathrm{~A}$ & 16.1 & 15.2 & $15.7 \mathrm{~A}$ & 4.0 & 3.8 & $3.9 \mathrm{~A}$ \\
\hline Mean & $4.1 \mathrm{a}$ & $3.8 \mathrm{a}$ & & $16.4 \mathrm{a}$ & $15.7 \mathrm{a}$ & & $4.1 \mathrm{a}$ & $4.0 \mathrm{a}$ & \\
\hline \multicolumn{10}{|c|}{ "Fuji Suprema" 2010/2011 cycle } \\
\hline Open sky & - & - & - & - & - & - & - & - & - \\
\hline Hail net & 2.8 & 2.7 & 2.8 & 14.6 & 13.7 & 14.2 & 5.3 & 5.1 & 5.2 \\
\hline Mean & - & - & & - & - & & - & - & \\
\hline
\end{tabular}

Uppercase letters in the column of the mean and lowercase letters on the line of the mean indicate statistically significant differences by Tukey's test ( $p \leq$ 0.05). The en dash (-) indicates no data due to the total loss of production under the open sky because of hail

overall acceptability did not differ significantly between the "Royal Gala" apples produced under the open sky and under the anti-hail net. According to Table 4, the $F$ values (analysis of variance) obtained in the samples were smaller than the critical $F$ for all attributes evaluated, indicating no significant differences between the fruit samples.

The attributes of appearance and skin color were considered best for "Fuji Suprema" apples produced under the antihail net because the fruits were redder. The sweet flavor, acid flavor, and overall acceptability of the fruits did not differ significantly between environments for the "Fuji Suprema" apples (Table 4).

\section{Discussion}

Under the conditions of southern Brazil, the microclimatic changes in apple orchards caused by a black anti- hail net with $4 \times 7 \mathrm{~mm}$ mesh had almost no effect on the physical, chemical, or sensory characteristics of the fruits. The interaction of solar radiation with the density and management of the plants determined the quality of the fruits, corroborating the assessments conducted by Grappadelli (2003), Solomakhin and Blanke (2007) and Tanny (2013).

The fruits located in the upper and lower canopy layers were naturally exposed to different levels of shading, as the several leaf layers of the plants also influence the direct incidence of radiation on the fruit. The shading in the lower layers was not decisive for the quality of the fruit given the size of the spacing between the rows of plants $(3.5 \mathrm{~m})$ and the way of conduction in the central leader format. In addition, it is important to note that, over the years, apple clones with more colorful fruits have been selected through breeding, which can determine less significant differences between growing environments. 
Table 4 Analysis of variance for sensory attributes of "Royal Gala" and "Fuji Suprema" apples produced under open sky and anti-hail net protection in the 2009/2010 cycle, Vacaria, RS, Brazil

\begin{tabular}{|c|c|c|c|c|c|c|c|c|c|c|}
\hline \multirow[t]{2}{*}{ Source of variation } & \multicolumn{5}{|c|}{ "Royal Gala" } & \multicolumn{5}{|c|}{ "Fuji Suprema" } \\
\hline & DF & MS & $F_{\text {calculated }}$ & $p$ & $F_{\text {critical }}$ & $\mathrm{DF}$ & MS & $F_{\text {calculated }}$ & $p$ & $F_{\text {critical }}$ \\
\hline \multicolumn{11}{|c|}{ Visual attribute (appearance) } \\
\hline Tasters & 33 & 3.77 & 2.23 & 0.01 & 1.79 & 31 & 2.44 & 1.58 & 0.11 & 1.82 \\
\hline Samples & 1 & 2.12 & 1.25 & 0.27 & 4.14 & 1 & 8.27 & 5.32 & 0.03 & 4.16 \\
\hline Error & 33 & 1.69 & & & & 31 & 1.56 & & & \\
\hline Total & 67 & & & & & 63 & & & & \\
\hline \multicolumn{11}{|c|}{ Visual attribute (color tone) } \\
\hline Tasters & 33 & 2.84 & 1.25 & 0.27 & 1.79 & 31 & 3.45 & 1.73 & 0.07 & 1.82 \\
\hline Samples & 1 & 3.76 & 1.66 & 0.21 & 4.14 & 1 & 16 & 8.0 & 0.009 & 4.16 \\
\hline Error & 33 & 2.28 & & & & 31 & 2 & & & \\
\hline Total & 67 & & & & & 63 & & & & \\
\hline \multicolumn{11}{|c|}{ Taste attribute (sweet taste) } \\
\hline Tasters & 33 & 2.13 & 1.78 & 0.05 & 1.79 & 31 & 1.25 & 1.61 & 0.09 & 1.82 \\
\hline Samples & 1 & 0.01 & 0.01 & 0.91 & 4.14 & 1 & 1 & 1.29 & 0.26 & 4.16 \\
\hline Error & 33 & 1.19 & & & & 31 & 0.77 & & & \\
\hline Total & 67 & & & & & 63 & & & & \\
\hline \multicolumn{11}{|c|}{ Taste attribute (acid taste) } \\
\hline Tasters & 33 & 4.65 & 1.96 & 0.03 & 1.79 & 31 & 2.39 & 0.91 & 0.60 & 1.82 \\
\hline Samples & 1 & 2.88 & 1.22 & 0.28 & 4.14 & 1 & 1 & 0.38 & 0.54 & 4.16 \\
\hline Error & 33 & 2.37 & & & & 31 & 2.61 & & & \\
\hline Total & 67 & & & & & 63 & & & & \\
\hline \multicolumn{11}{|c|}{ Overall acceptability attributes } \\
\hline Tasters & 33 & 2.26 & 1.96 & 0.03 & 1.79 & 31 & 1.54 & 1.30 & 0.24 & 1.82 \\
\hline Samples & 1 & 2.48 & 2.16 & 0.15 & 4.14 & 1 & 0.77 & 0.65 & 0.43 & 4.16 \\
\hline Error & 33 & 1.15 & & & & 31 & 1.19 & & & \\
\hline Total & 67 & & & & & 63 & & & & \\
\hline
\end{tabular}

When $F_{\text {calculated }}$ has a value greater than $F_{\text {critical, }}$, there is a significant difference between the environments, $p=5 \%$ probability of error $D F$ degrees of freedom, $M S$ mean square

Fruit exposed to direct solar radiation and temperatures between 15 and $20{ }^{\circ} \mathrm{C}$ for at least 20 days before harvest can synthesize a higher concentration of anthocyanins, which determine the red color of the fruits (Arakawa 1988, 1991). The quantity and quality of the radiation that reaches the fruit influences the synthesis of anthocyanins (Ubi BE 2004). Studies have shown that radiation at blue-violet and ultraviolet wavelengths is more effective in the formation of anthocyanin than is far-red radiation, which may have an inhibitory effect (Reay and Lancaster 2001). The red/far-red (R/FR) ratio can also influence the levels of anthocyanins. Awad et al. (2001) observed that when the R/FR ratio was less than 1.0, there was a decrease in the levels of anthocyanins and flavonoids. The synthesis of anthocyanins may also be related to hormonal factors through the reduction of gibberellins or increases in the level of ethylene and/or abscisic acid (Saure 1990). The radiation quality was not altered by the anti-hail net, and the R/FR ratio, measured just under the net, was greater than 1.0. The interaction of solar radiation with the canopy (middle and lower layers) caused changes in the radiation quality under the net, but these were not enough to change the fruit color. A possible explanation is that the reduction of PAR under the net may have been offset by changes in the radiation spectrum in the middle and lower layers of this environment (Table 5).

Guerrero-Prieto et al. (2010), Smit (2007), and Dussi et al. (2005) concluded that use of a black net does not change the fruit color. However, other studies report that there is a reduction in the fruit color when grown under a net compared to those grown under the open sky (Solomakhin and Blanke 2010b; 
Table 5 Distribution of different solar radiation wavelengths (percentage relative to the incident solar radiation) in the upper, middle, and lower strata and interrows of the "Fuji Suprema" apple orchard under the anti-hail net (HN) or open sky (OS) on a sunny day (03/31/2010), Vacaria, RS, Brazil

\begin{tabular}{|c|c|c|c|c|c|c|c|c|}
\hline \multirow[t]{3}{*}{ Wavelengths (nm) } & \multicolumn{8}{|c|}{ Solar radiation $(\%)$} \\
\hline & \multicolumn{2}{|c|}{ Upper } & \multicolumn{2}{|c|}{ Middle } & \multicolumn{2}{|c|}{ Lower } & \multicolumn{2}{|c|}{ Interrow } \\
\hline & $\mathrm{HN}$ & OS & $\mathrm{HN}$ & OS & $\mathrm{HN}$ & OS & $\mathrm{HN}$ & OS \\
\hline $300-350$ & 0.2 & 0.2 & 0.1 & 0.2 & 0.1 & 0.2 & 0.2 & 0.2 \\
\hline $350-400$ & 1.2 & 1.2 & 0.9 & 1.0 & 0.5 & 0.9 & 1.0 & 1.0 \\
\hline $400-450$ & 5.2 & 5.1 & 4.3 & 3.9 & 1.9 & 3.1 & 4.8 & 4.7 \\
\hline $450-500$ & 10.2 & 10.3 & 8.8 & 6.1 & 3.8 & 5.2 & 9.7 & 9.7 \\
\hline $500-550$ & 13.0 & 13.0 & 11.7 & 7.4 & 7.5 & 7.5 & 12.6 & 12.6 \\
\hline $550-600$ & 16.9 & 16.8 & 15.1 & 13.2 & 10.4 & 9.7 & 16.5 & 16.5 \\
\hline $600-650$ & 17.7 & 17.7 & 15.7 & 17.6 & 9.9 & 8.4 & 17.4 & 17.5 \\
\hline $650-700$ & 14.7 & 14.8 & 13.7 & 15.0 & 7.9 & 6.4 & 14.5 & 14.7 \\
\hline $700-750$ & 11.3 & 11.3 & 14.1 & 16.2 & 22.8 & 22.6 & 12.2 & 12.1 \\
\hline $750-800$ & 9.6 & 9.7 & 15.6 & 19.4 & 35.2 & 35.9 & 11.2 & 11.0 \\
\hline Ratio R/FR & 1.55 & 1.58 & 1.11 & 1.00 & 0.31 & 0.27 & 1.40 & 1.43 \\
\hline
\end{tabular}

$R / F R$ ratio of radiation in the red $(600-700 \mathrm{~nm})$ and far-red $(700-800 \mathrm{~nm})$ bands

Amarante et al. 2009, 2007; Jakopic et al. 2007; Iglesias and Alegre 2006; Dussi et al. 2005; Stampar et al. 2002; Leite et al. 2002). In these studies, different cultivars were used, and the fruits under the net were harvested on the same day as those under the open sky, clearly demonstrating the differences between environments. Aside from the harvest time, the method used to determine the color of the fruits in the several existing studies might also have influenced the interpretation of the results. In general, fruits with greater exposure to solar radiation (under open sky) acquire a reddish color faster than do those under an anti-hail net, shortening the production cycle. The difference in the fruit ripening time between environments is relevant to the management of orchards, as it allows for the timing of the harvest and, hence, a reduced demand for manpower.

Maturation and fruit flavor are important characteristics of fruit quality. The TSS/TTA ratio is considered to be a better indicator of these factors than are the levels of TSS and TTA observed individually. During maturation, the TSS/TTA ratio increases due to the decrease in acids and increase in sugars, and the absolute value depends upon the cultivar (Fachinello et al. 1996). The fruits harvested under the net have sensory characteristics that are similar to those grown under the open sky. This result, together with those related to fruit color, provides unequivocal evidence that the black anti-hail net used in apple orchards in southern Brazil does not affect the characteristics of "Royal Gala" and "Fuji Suprema" apples.
Given the results of the present study and the scenarios of increased occurrence of extreme events due to climate change, apple producers may be instructed to use anti-hail protection nets to protect their orchards. This incentive may originate from public agencies linked to agriculture through grants and technical assistance because in Brazil, the cost of the use of anti-hail nets is considered high in terms of total production costs (Sobczak 2011). A single occurrence of intense hail in the apple orchard justifies the investment in such nets, as the net is a physical barrier that prevents damage from occurring to the fruits and plants (Garnaud 1998; Sobczak 2011), ensuring the production of the current and future crops without compromising the quality of the fruit.

\section{Conclusion}

The physical, chemical, and sensory attributes of "Royal Gala" and "Fuji Suprema" apples are not altered by the use of black anti-hail nets over orchards.

Coverage by a black anti-hail net does not affect the fruit color indices, TSS, TSS/TTA ratio, or taste of "Royal Gala" and "Fuji Suprema" apples produced in southern Brazil.

The use of anti-hail nets on apple orchards is a suitable alternative for the protection of apple trees against hail because it causes only small changes in the maturation period, ensuring fruit production without affecting its quality. 


\section{References}

Alvares CA, Stape JL, Sentelhas PC, Gonçalves JLM, Sparovek G (2013) Köppen's climate classification map for Brazil. Meteorol Z 22:711728. doi:10.1127/0941-2948/2013/0507

Amarante CVT, Steffens CA, Mota CS, Santos HP (2007) Radiation, photosynthesis, yield, and fruit quality of 'Royal Gala' apples under hail protection nets. Pesq Agrop Brasileira 42:925-931. doi:10. 1590/S0100-204X2007000700003

Amarante CVT, Steffens CA, Miqueloto A, Zanardi OZ, Santos HP (2009) Light supply to 'Fuji' apple trees covered with hail protection nets and its effects on photosynthesys, yield and fruit quality. Rev Bras Frutic 31:664-670. doi:10.1590/S0100-29452009000300007

Amarante CVT, Steffens CA, Argenta LC (2011) Yield and fruit quality of 'Gala' and 'Fuji' apple trees protected by white anti-hail net. Sci Hortic 129:79-85. doi:10.1016/j.scienta.2011.03.010

Arakawa O (1988) Characteristics of colour development in some apple cultivars: changes in anthocyanin synthesis during maturation as affected by bagging and light quality. J Jpn Soc Hortic Sci 57: 373-380. doi:10.2503/jishs.57.373

Arakawa O (1991) Effect of temperature on anthocyanin accumulation in apple fruit as affected by cultivar, stage of fruit ripening and bagging. J Hortic Sci 66:763-768

Awad MA, Wagenmakers PS, Jager A (2001) Effects of light on flavanoid and chlorogenic acid levels in the skin of 'Jonagold' apples. Sci Hortic 88:289-298. doi:10.1016/S0304-4238(00)00215-6

Cardoso LS (2011) Modeling the phenology of 'Royal Gala' and 'Fuji Suprema' apple trees in function of the climate, in the Vacaria region, Brazil. Thesis, University Federal of Rio Grande do Sul, Brazil

Cardoso LS, Bergamaschi H, Bosco LC, Paula VA, Marodin GAB, Casamali B, Nachtigall GR (2012) Climate availability for apple trees in Vacaria, southern Brazil. Ciênc Rural 42:1960-1967. doi:10. 1590/S0103-84782012005000097

Dussi MC, Giardina G, Sosa D, González JR, Zecca A, Reeb P (2005) Shade nets effect on canopy light distribution and quality of fruit and spur leaf on apple cv. Fuji. Span J Agric Res 3:253-260. doi:10.5424/144

Dutcosky SD (2011) Sensory analysis of foods. Champagnat, Curitiba

EMBRAPA-Empresa Brasileira de Pesquisa Agropecuária (2006) Brazilian system of soil classification. Embrapa Solos, Rio de Janeiro

Fachinello JC, Nachtigal JC, Kersten E (1996) Fruit production: principles and practice. UFPEL, Pelotas

Faust M, Shear CB (1972) Russeting of apples, an interpretive review. HortSci 7:233-235

Garnaud JC (1998) Hail protection nets on fruit. Horticultura Internacional 1:19-23

Grappadelli LC (2003) Light relations. In: Ferree DC, Warrington IJ (eds) Apples: botany, production and uses. CABI, Wallingford, pp 195-213

Guerrero-Prieto VM, Roa-Solís P, Chacón-Blanco R, Jiménez-Castro JA, Sánchez-Chávez E (2010) 'Red Delicious' apple fruit color under hail nets in Mexico. Tecnociencia Chihuahua 4:7-11

Iglesias I, Alegre S (2006) The effect of anti-hail nets on fruit protection, radiation, temperature, quality and profitability of 'Mondial Gala' apples. J Appl Hortic 8:91-100
Jakopic J, Veberic R, Stampar F (2007) The effect of reflective foil and hail nets on the lighting, color and anthocyanins of 'Fuji' apple. Sci Hortic 115:40-46. doi:10.1016/j.scienta.2007.07.014

Leite GB, Petri JL, Mondardo M (2002) Effects of net shield against hailstorm on feature of apples production and fruit quality. Rev Bras Frutic 24:714-716. doi:10.1590/S0100-29452002000300037

Middleton S, McWaters A (2002) Hail netting of apple orchardsAustralian experience. Compact Fruit Tree 35:51-55

Noé N, Eccher T (1996) 'Golden Delicious' apple fruit shape and russeting are affected by light conditions. Sci Hortic 65:209-213. doi:10. 1016/0304-4238(95)00850-0

NTEPI-Specific technical guidelines for integrated production of apple (2006) Normative Instruction 1/2006 of the Secretary of Agriculture and Cooperative Development, Ministry of Agriculture, Livestock and Supply. http://sistemasweb.agricultura.gov.br/sislegis/action/ detalhaAto.do?method=visualizarA toPortalMapa\&chave $=$ 1622859255. Accessed 23 February 2014

Pereira TP, Fontana DC, Bergamaschi H (2009) The climate of the Campos de Cima da Serra Region, Rio Grande do Sul state, Brazil: thermal and water conditions. Pesq Agrop Gaúcha 15: $145-157$

Reay PF, Lancaster JE (2001) Accumulation of anthocyanins and quercetin glycosides in 'Gala' and 'Royal Gala' apple fruit skin with UVB-Visible irradiation: modifying effects of fruit maturity, fruit side, and temperature. Sci Hortic 90:57-68. doi:10.1016/S0304-4238(00) 00247-8

Saure MC (1990) External control of anthocyanin formation in apple. Sci Hortic 42:181-218. doi:10.1016/0304-4238(90)90082-P

Smit A (2007) Apple tree and fruit responses to shade netting. Dissertation, University of Stellenbosch

Sobczak A (2011) The danger that comes from heaven, with an increasingly unpredictable climate, fruit growers have sought alternatives to minimize the damage. Rev Panorama Rural 1:1-6

Solomakhin A, Blanke MM (2007) Overcoming adverse effects of hailnets on fruit quality and microclimate in an apple orchard. J Sci Food Agric 87:2625-2637. doi:10.1002/jsfa.3022

Solomakhin A, Blanke MM (2010a) The microclimate under coloured hailnets affects leaf and fruit temperature, leaf anatomy, vegetative and reproductive growth as well as fruit coloration un apple. Ann Appl Biol 156:121-136. doi:10.1111/j.1744-7348.2009.00372.x

Solomakhin A, Blanke MM (2010b) Can coloured hailnets improve taste (sugar, sugar: acid ratio), consumer appeal (colouration) and nutritional value (anthocyanin, vitamin C) of apple fruit? LWT Food Sci Technol 43:1277-1284. doi:10.1016/j.lwt.2010.02.020

Stampar F, Veberic R, Zadravec FP, Hudina M, Usenik V, Solar A, Osterc G (2002) Yield and fruit quality of apples cv. 'Jonagold' under hail protection nets. Eur J Hortic Sci 67:205-210

Tanny J (2013) Microclimate and evapotranspiration of crops covered by agricultural screens: a review. Biosyst Eng 114:26-43. doi:10.1016/ j.biosystemseng.2012.10.008

Tanny J, Cohen S, Grava A, Naor A, Lukyanov V (2009) The effect of shading screens on microclimate of apple orchards. Acta Horticult 807:103-108

Ubi BE (2004) External stimulation of anthocyanin biosynthesis in apple fruit. J Food Agr Environ 2:65-70 